\title{
The Secretion of Newly Synthesized Insulin in vitro
}

\author{
BY S. L. HOWELL AND K. W. TAYLOR \\ Department of Medicine and Diabetic Department, \\ King's College Hospital Medical School, Denmark Hill, London, S.E. 5
}

(Received 18 July 1966)

\begin{abstract}
1. An immunological method for the purification of small quantities of insulin has been devised. 2. This method has been used to isolate labelled insulin secreted from pancreas slices incubated in vitro. The insulin had previously been labelled by incubation of the slices with $\left[{ }^{3} \mathrm{H}\right]$ leucine in vitro. 3. There is some release of labelled insulin when such slices are further incubated in media of low glucose content. When the glucose content of the medium is raised, little additional radioactive insulin is released in the first hour after labelling. However, there is a marked increase in specific radioactivity of insulin released from slices in response to a high concentration of glucose in the second and third hours. Release of labelled insulin is again diminished in the final phase, $4 \mathrm{hr}$. from the start of the experiment. 4. These results are discussed in relation to possible mechanisms of insulin release from the $\beta$-cell.
\end{abstract}

Up to the present there is little information available about the rate at which newly synthesized insulin may be released from the $\beta$-cells of memmalian pancreas under the influence of sugars. A study of this kind should establish whether or not newly synthesized insulin is secreted very shortly after its synthesis, as seems to be the case with albumin (Peters, 1962), or whether there is a delay in release due to accumulation of newly synthesized insulin within $\beta$-granules. It has already been shown by Caro \& Palade (1964) that release of digestive enzymes from exocrine pancreas through zymogen granules takes place in $2-3 \mathrm{hr}$. after synthesis of the proteins within them.

The use of isolated pancreas slices in vitro for the study of the synthesis and secretion of insulin has already byen described (Mallory, Smith \& Taylor, 1964; Coore \& Randle, 1964), and it seems that this preparation may serve as a physiological model for islet-cell function in vivo. Islet tissue incubated in vitro has a normal appearance on electron microscopy (see Williamson, Lacy \& Taylor, 1967).

In the present paper, a method for the isolation of small quantities of radioactively labelled insulin released from rabbit pancreas slices incubated in vitro is described. By the use of this technique the release of labelled insulin in the presence of high concentrations of glucose from pancreas slices, which had previously been incubated with [ $\left.{ }^{3} \mathrm{H}\right]-$ leucine, has been studied during a $4 \mathrm{hr}$. period. Under these conditions there appears to be no release of labelled insulin in response to glucose during the first hour after synthesis, although this is not the case in the later time-periods studied.

These results are discussed in the light of existing information on the secretion of newly synthesized proteins as well as with reference to possible modes of secretion of insulin.

\section{MATERIALS AND METHODS}

Radioactive materials. DL- $\left[4,5-{ }^{3} \mathrm{H}_{2}\right]$ Leucine of specific activity 9000 or $23000 \mathrm{c} / \mathrm{mole}$ and 131I-iodinated insulin of specific activity approx. $50 \mathrm{mc} / \mathrm{mg}$. were obtained from The Radiochemical Centre, Amersham, Bucks.

Chemicals. D-Glucose of A.R. quality (Hopkin and Williams Ltd., Chadwell Heath, Essex) and bovine serum albumin fraction V (Armour Pharmaceutical Co. Ltd., Eastbourne, Sussex) were used. All other chemicals were of A.R. grade.

Insulin. Ox insulin for use as carrier, as marker material on chromatograms, or as standards in the assay of insulin, was a recrystallized specimen kindly provided by the Wellcome Research Laboratories, Beckenham, Kent.

Preparation of anti-insulin serum. This was prepared in guinea pigs by repeated injection of crystalline ox insulin emulsified in Freund's complete adjuvant (Jones \& Cunliffe, 1961). For this purpose a solution of insulin $(2 \mathrm{mg} . / \mathrm{ml}$.) in $0.01 \mathrm{~N}-\mathrm{HCl}$ was emulsified by vigorous shaking with an equal volume of Freund's complete adjuvant; $0.5 \mathrm{ml}$. of this mixture was injected subcutaneously into guinea pigs, followed by a further $0.25 \mathrm{ml}$. after one month. Blood was drawn for separation of the precipitating antiserum after a further 4 weeks.

Preparation of anti- $\gamma$-globulin serum. This was made in rabbits by weekly subcutaneous injections at several sites of $10 \mathrm{mg}$. quantities of guinea-pig $\gamma$-globulin extracted and emulsified for injection by the method described by Hales 
\& Randle (1963). Ten days after the last of six such weekly injections, blood was taken from the marginal vein of the ear of unanaesthetized animals and allowed to clot. The serum, after separation by centrifuging, was titrated against an equal volume of normal guinea-pig serum and was considered satisfactory for use if a visible precipitate was obtained after $3 \mathrm{hr}$. at $37^{\circ}$ with dilutions of normal guineapig serum of 1:5000 or above. In earlier experiments, rabbit anti-(guinea-pig $\gamma$-globulin) sera were kindly provided by Dr M. Wood, Wellcome Research Laboratories.

Insulin assay. The radioimmunoassay method of Hales \& Randle (1963) was used for the estimation of insulin. Anti-insulin serum and antiserum to guinea-pig serum proteins made in rabbits were prepared at the Wellcome Laboratories; both were obtained from The Radiochemical Centre. Ox insulin standards were used throughout; it has been suggested that purified rabbit insulin behaves very similarly to crystalline ox insulin in this method of immunoassay (Coore \& Randle, 1964). The same antiserum was used in the various phases of each experiment. It has been assumed that, over the small range of insulin values measured, there is unlikely to be any significant deviation from parallelism in dose-response curves when rabbit insulin and ox insulin are compared when different batches of antiserum are used.

Preparation of tissue for incubation. Male rabbits weighing $2 \cdot 5-3 \mathrm{~kg}$. of a New Zealand White strain were used. In a typical experiment, three animals were starved overnight before use, but given $5 \%$ glucose in water to drink. They were killed quickly by the intravenous injection of Nembutal (Abbott Laboratories Ltd., Queenborough, Kent) at a dose of $60 \mathrm{mg} . / \mathrm{kg}$. into the marginal vein of the ear. The portion of the pancreas running alongside the spleen was immediately removed into ice-cold medium of low glucose content $(50 \mathrm{mg} . / 100 \mathrm{ml}$.) in a Petri dish, and trimmed free of excess of fat and large blood vessels before being cut with scissors into slices approx. $60 \mathrm{mg}$. in weight; ice-cold medium was used so as to minimize disintegration of the tissue by proteolytic enzymes.

Incubation procedure. The basal medium for incubation of the pancreas slices was a bicarbonate-buffered salt mixture, gassed with $\mathrm{O}_{2}+\mathrm{CO}_{2}(95: 5)$ (Gey \& Gey, 1936).

The tissue slices were drained free of surplus medium and distributed in two $500 \mathrm{ml}$. Erlenmeyer flasks containing $20 \mathrm{ml}$. of basal medium. The glucose concentration of this medium was $250 \mathrm{mg} . / 100 \mathrm{ml}$., and it contained in addition $\left[{ }^{3} \mathrm{H}\right]$ leucine $(2.5 \mathrm{mc} / 100 \mathrm{ml}$.) and normal human serum $(2.5 \mathrm{ml} . / 100 \mathrm{ml}$.). After gassing the slices were incubated with gentle shaking in a water bath at $37^{\circ}$ for $20 \mathrm{~min}$.

The surplus medium was now poured off and the slices were washed in situ with a large volume of non-radioactive medium containing a low concentration of glucose $(50 \mathrm{mg}$. $100 \mathrm{ml}$.). After being regassed they were then reincubated with $40 \mathrm{ml}$. of medium of low glucose content for $10 \mathrm{~min}$., this period constituting a resting phase. The slices were then pooled and redistributed in two further $500 \mathrm{ml}$. flasks, each containing $20 \mathrm{ml}$. of medium and albumin at a concentration of $200 \mathrm{mg} . / 100 \mathrm{ml}$. One flask contained glucose at a concentration of $50 \mathrm{mg} . / 100 \mathrm{ml}$., designated 'low', and the other contained glucose at $250 \mathrm{mg}$. $/ 100 \mathrm{ml}$., designated 'high'. After being gassed, the flasks were incubated at $37^{\circ}$ with gentle shaking for $1 \mathrm{hr}$. (incubation phase A) (see Table 1). At the end of this period, 30-90 min. from the start of labelling, the medium in each flask was poured off completely and chilled to $4^{\circ}$ before extraction for determination of its insulin content. The tissue remaining in each flask was washed with medium of the appropriate glucose content before replacement with a further $20 \mathrm{ml}$. of medium whose constitution in each case was identical with that used in the previous $1 \mathrm{hr}$. incubation. Both flasks were incubated for a further hour as before; this was designated phase $B$, representing a period $1 \frac{1}{2}-2 \frac{1}{2} \mathrm{hr}$. from the start of labelling. This cycle was repeated for two further $1 \mathrm{hr}$. periods, which were $2 \frac{1}{2}-3 \frac{1}{2}$ and $3 \frac{1}{2}-4 \frac{1}{2} \mathrm{hr}$. from the start of the experiment (phases $\mathrm{C}$ and $\mathrm{D}$ ). The whole sequence of incubations is outlined in Table 1. At the conclusion of each $1 \mathrm{hr}$. phase the medium was cooled to $4^{\circ}$ and the extraction of insulin begun immediately after the completion of the experiment.

In some early experiments, the tissue was incubated with labelled leucine under conditions identical with those described above, for $1 \mathrm{hr}$. instead of for $20 \mathrm{~min}$. The slices were then incubated for $30 \mathrm{~min}$. in medium of low glucose concentration $(50 \mathrm{mg} . / 100 \mathrm{ml}$.) before mixing and redistribution in two flasks, containing glucose at concentrations of 50 and $250 \mathrm{mg}$. $/ 100 \mathrm{ml}$., for a single $1 \mathrm{hr}$. incubation. The insulin released into the media was then extracted and purified for determination of its specific radioactivity.

Extraction of insulin from the medium. After completion of each incubation phase, a small volume $(0 \cdot 1 \mathrm{ml}$.) of the

Table. 1. Sequence of incubations in experiments designed to study insulin release in vitro during a $4 \mathrm{hr}$. period

Designation of incubation period in the text

Labelling

Resting
Time from start of expt. $0-20 \mathrm{~min}$. 20-30 min. $30 \mathrm{~min}$.
Concn. of glucose in medium (mg./100 ml.)

250

50

Tissue distributed equally into two flasks for subsequent incubations

$\begin{array}{cc}\text { Flask 1 } & \text { Flask 2 } \\ 50 & 250 \\ 50 & 250 \\ 50 & 250 \\ 50 & 250\end{array}$

lask 2

250

250
Phase A

Phase B

Phase C

Phase D $\frac{1}{2}-1 \frac{1}{2} \mathrm{hr}$.
$1 \frac{1}{2}-2 \frac{1}{2} \mathrm{hr}$.
$2 \frac{1}{2}-3 \frac{1}{2} \mathrm{hr}$.
$3 \frac{1}{2}-4 \frac{1}{2} \mathrm{hr}$. 
medium was removed and diluted with a $0.04 \mathrm{M}-\mathrm{NaH}_{2} \mathrm{PO}_{4}$ buffer, containing bovine serum albumin $(0 \cdot 1 \%)$ and thiomersalate $(0.6 \mathrm{~mm})$, which was previously adjusted to pH7.4 with $2 \mathrm{~N}-\mathrm{NaOH}$. The diluted medium was stored at $-20^{\circ}$ for determination of its insulin content by immunoassay at a later date. The remainder of the medium was chilled to $4^{\circ}$ and the protein precipitated with an equal volume of trichloroacetic acid $(10 \%, w / v)$. The precipitate was washed with $5 \%(\mathrm{w} / \mathrm{v})$ trichloroacetic acid and dissolved in $5 \mathrm{ml}$. of ethanol- $0.8 \mathrm{~N}-\mathrm{HCl}(3: 1, \mathrm{v} / \mathrm{v})$, any sediment remaining being discarded before adjustment of the $\mathrm{pH}$ of the solution to 8 with aq. $5 \mathrm{~N}-\mathrm{NH}_{3}$ solution. The precipitate formed was rejected and the clear supernatant containing the insulin was treated with a mixture of $2 \frac{1}{2} \mathrm{vol}$. of ether and $1 \frac{1}{2}$ vol. of ethanol and left in the cold (Grodsky \& Tarver, 1956). The resultant precipitate was removed by centrifuging, washed with ether, dissolved in $1.0 \mathrm{ml}$. of $0.03 \mathrm{~N}-\mathrm{HCl}$ and diluted with $0.15 \mathrm{M}-\mathrm{NaCl}$ to a total volume of $10 \mathrm{ml}$. The crude insulin solution was then dialysed in Visking tubing (24/32 in.) against distilled water at $4^{\circ}$. The non-diffusible residue was transferred to a suitable flask for freeze-drying of the protein before purification of the insulin present.

Purification of extracted insulin. Insulin extracted from the media was purified by a 'double-antibody' technique in which precipitation of insulin bound to the $\gamma$-globulin antibodies of a guinea-pig anti-insulin serum was achieved by a rabbit anti-(guinea-pig $\gamma$-globulin) serum. The freezedried protein was dissolved in $2.5 \mathrm{ml}$. of a mixture of $0.03 \mathrm{~N}$ $\mathrm{HCl}$ and $0.15 \mathrm{M}-\mathrm{NaCl}$ and incubated in a water bath at $37^{\circ}$ for $3 \mathrm{hr}$. with $0.5 \mathrm{ml}$. of an anti-insulin serum. The $\gamma$ globulin fraction containing the insulin-antibody complex was then precipitated with the optimum volume of an anti(guinea-pig $\gamma$-globulin) serum, as determined for each batch of serum, and incubated for a further hour. The flocculent precipitate formed was spun down and washed four times with $0 \cdot 15 \mathrm{M}-\mathrm{NaCl}$, the supernatant being rejected, before regeneration of the insulin by the addition of $0.5 \mathrm{ml}$. of ethanol-0.8 N-HCl (3:1, v/v) (Taylor, Gardner, Parry \& Jones, 1965). A small portion of the ethanolic extract was diluted with $0.04 \mathrm{M}$-phosphate buffer, $\mathrm{pH} 7.4$, for determination of its insulin content by immunoassay. To $0.3 \mathrm{ml}$. of the remainder was added $100 \mu \mathrm{g}$. of ox insulin in $0.1 \mathrm{ml}$. of $0.03 \mathrm{~N}-\mathrm{HCl}$ to act as carrier material. The combined solutions were then applied to paper for further purification by two-dimensional chromatography and electrophoresis. The distribution of radioactivity along the strip was determined by methods that have already been described (Mallory et al. 1964).

\section{RESULTS}

Fig. 1 shows the distribution of radioactivity along the paper after electrophoresis of labelled insulin secreted into the incubation medium which had been purified by the 'double-antibody' precipitation method. The precipitate obtained with antibody was extracted with acidic ethanol and further chromatographed on paper in butan2-ol-aq. $1 \%$ acetic acid $(1: 1, \mathrm{v} / \mathrm{v})$. It was then subjected to paper electrophoresis at $\mathrm{pH} 1.8$ by using methods already described (Taylor \& Smith, 1964). Fig. 1 shows that a single peak of radio-

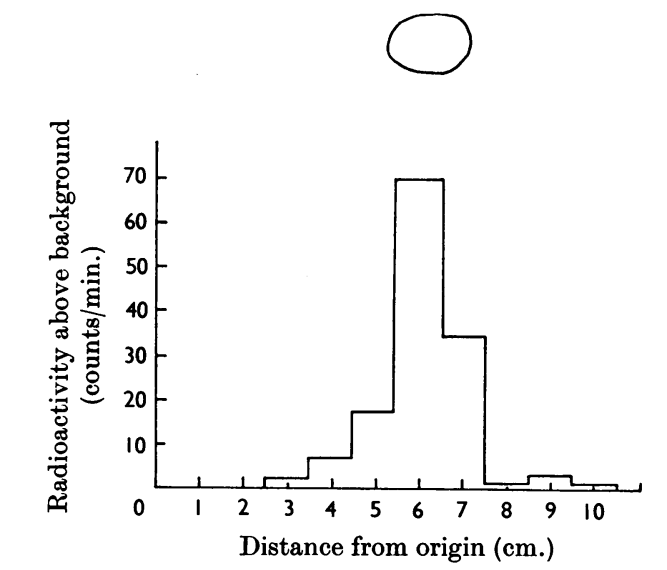

Fig. 1. Distribution of radioactivity on paper after electrophoresis at $\mathrm{pH} 1.8$ of labelled insulin extracted from incubation media, after release from pancreas slices previously incubated in vitro with $\left[{ }^{3} \mathrm{H}\right]$ leucine. Insulin was extracted from the medium with acidic ethanol, precipitated by ether-ethanol and purified by immunoprecipitation before chromatography and electrophoresis. The electrophoretogram was cut into $1 \mathrm{~cm}$. strips for counting. The spot represents the position of a marker of $100 \mu \mathrm{g}$. of ox insulin after electrophoresis in the same system.

activity was obtained, and that this approximates to the position of crystalline ox insulin added as marker.

In Table 2 are shown the specific radioactivities of insulin secreted into the medium after a $1 \mathrm{hr}$. incubation with label. The release of insulin was studied in a period $1 \frac{1}{2}-2 \frac{1}{2} \mathrm{hr}$. from the start of labelling.

There was some release of labelled insulin when the slices were incubated in medium of low glucose content. In medium of high glucose content the specific radioactivity of insulin released falls by about a half whereas under these conditions the absolute amount of insulin secreted rises approximately fourfold.

In the experiments shown in Table 3, insulin had been labelled for a period of only $20 \mathrm{~min}$., and release was studied in four successive $1 \mathrm{hr}$. periods after the end of the labelling incubation.

The release of insulin into medium of high glucose content was at a similar level throughout the four periods in which it was studied, and in the final $3 \mathrm{hr}$. was approx. four times that seen in a low glucose medium. In the first hour, however, the amount of insulin released in medium of high glucose content was about twice that released in medium of low glucose content, owing to additional release of insulin into the medium of low glucose content. This may be a result of residual secretory 


\section{Table 2. Release of labelled insulin in vitro $1 \frac{1}{2}-2 \frac{1}{2} \mathrm{hr}$. after a $1 \mathrm{hr}$. period of labelling}

Rabbit pancreas slices were incubated in vitro with $\left[{ }^{3} \mathrm{H}\right]$ leucine in medium of high glucose content for $1 \mathrm{hr}$. and, after a $30 \mathrm{~min}$. resting period, reincubated in media with glucose concentrations of $50 \mathrm{or} 250 \mathrm{mg}$. $/ 100 \mathrm{ml}$., for a further $1 \mathrm{hr}$. period. Insulin released into the media during the second period was extracted by acidic ethanol and purified by immunoprecipitation, before paper chromatography and electrophoresis of the product and determination of the distribution of radioactivity along the paper strip. The insulin content of the media and extracts was determined by radioimmunoassay, and the specific radioactivity of the insulin thus calculated (for details see the text).

$\begin{array}{cccc}\text { Expt. no. } & \begin{array}{c}\text { Into medium } \\ \text { containing } 50 \mathrm{mg} . \\ \text { of glucose } / 100 \mathrm{ml} .\end{array} & \begin{array}{c}\text { Into medium } \\ \text { containing } 250 \mathrm{mg} . \\ \text { of glucose } / 100 \mathrm{ml} .\end{array} & \begin{array}{c}\text { Rlucose medium/ } \\ \text { low-glucose } \\ \text { medium) } \\ \text { release (high- }\end{array} \\ 1 & 0 \cdot 17 & 0.66 & 3.88 \\ 2 & 0.22 & 0.82 & 3 \cdot 72\end{array}$

Sp. radioactivity of insulin (counts/min./ $\mu \mathrm{g}$.)

$\begin{array}{cc}\begin{array}{c}\text { Extracted from } \\ \text { medium containing } \\ 50 \mathrm{mg} \text {. of glucose/ } \\ \text { 100ml. }\end{array} & \begin{array}{c}\text { Extracted from } \\ \text { medium containing } \\ 250 \mathrm{mg} \text {. of glucose/ }\end{array} \\ 476 & 100 \mathrm{ml} . \\ 483 & 221 \\ & 281\end{array}$

Table 3. Release of previously labelled insulin in vitro $\frac{1}{2}-4 \frac{1}{2} h r$. after a $20 \mathrm{~min}$. labelling period

Rabbit pancreas slices were incubated in vitro with $\left[{ }^{3} \mathrm{H}\right]$ leucine for $20 \mathrm{~min}$. and, after a $10 \mathrm{~min}$. resting period in medium of low glucose content, reincubated in media with glucose concentrations of 50 or $250 \mathrm{mg}$. $/ 100 \mathrm{ml}$., for four successive $1 \mathrm{hr}$. periods, designated A, B, C and D. Insulin was extracted from the media with acidic ethanol and purified by immunoprecipitation before paper chromatography and electrophoresis of the product and determination of the distribution of radioactivity along the paper strip. The insulin content of the media and extracts was determined by immunoassay. Further details of the incubation procedure are given in Table 1.

\begin{tabular}{|c|c|c|c|c|}
\hline \multirow[b]{2}{*}{ Expt. no. } & \multirow[b]{2}{*}{ Incubation phase } & \multirow[b]{2}{*}{$\begin{array}{l}\text { Ratio of insulin release } \\
\text { (high-glucose medium/ } \\
\text { low-glucose medium) }\end{array}$} & \multicolumn{2}{|c|}{$\begin{array}{l}\text { Sp. radioactivity of insulin } \\
\text { (counts/min./ } / \mu \mathrm{g} .)\end{array}$} \\
\hline & & & $\begin{array}{c}\text { Extracted from } \\
\text { medium containing } \\
50 \mathrm{mg} . \text { of glucose } / \\
100 \mathrm{ml} .\end{array}$ & $\begin{array}{c}\text { Extracted from } \\
\text { medium containing } \\
250 \mathrm{mg} \text {. of glucose/ } \\
100 \mathrm{ml} .\end{array}$ \\
\hline 1 & $\begin{array}{l}\text { A } \\
\text { B } \\
\text { C } \\
\text { D }\end{array}$ & $\begin{array}{l}2 \cdot 62 \\
4 \cdot 48 \\
4 \cdot 80 \\
4 \cdot 71\end{array}$ & $\begin{array}{l}179 \\
233 \\
174 \\
370\end{array}$ & $\begin{array}{r}32 \\
103 \\
205 \\
117\end{array}$ \\
\hline 2 & $\begin{array}{l}\text { A } \\
\text { B } \\
\text { C } \\
\text { D }\end{array}$ & $\begin{array}{l}2 \cdot 18 \\
4 \cdot 04 \\
3 \cdot 39 \\
3 \cdot 94\end{array}$ & $\begin{array}{l}569 \\
635 \\
787 \\
-\end{array}$ & $\begin{array}{l}300 \\
291 \\
469 \\
244\end{array}$ \\
\hline 3 & $\begin{array}{l}\text { A } \\
\text { B } \\
\text { C } \\
\text { D }\end{array}$ & $\begin{array}{l}2 \cdot 32 \\
4 \cdot 13 \\
4 \cdot 16 \\
4 \cdot 45\end{array}$ & $\begin{array}{l}216 \\
242 \\
198 \\
-\end{array}$ & $\begin{array}{r}40 \\
124 \\
199 \\
75\end{array}$ \\
\hline 4 & $\begin{array}{l}\text { A } \\
\text { B } \\
\text { C } \\
\text { D }\end{array}$ & $\begin{array}{l}2 \cdot 50 \\
4 \cdot 89 \\
4 \cdot 38 \\
4 \cdot 99\end{array}$ & $\begin{array}{l}231 \\
314 \\
196\end{array}$ & $\begin{array}{r}47 \\
61 \\
130 \\
42\end{array}$ \\
\hline
\end{tabular}

activity of the $\beta$-cells after the original $20 \mathrm{~min}$. labelling period in a medium of high glucose content, the resting phase not being completely effective in returning the cells to an unstimulated condition. This short period was retained, however, since it was of importance to study the release of insulin as soon as possible after the end of the labelling period.

From the results it appears that the specific activity of the insulin released in the period $\frac{1}{2}$ $1 \frac{1}{2} \mathrm{hr}$. after the start of labelling falls very markedly in the medium of high glucose content relative to

Bioch. 1967, 102 
its control medium of low glucose content. This fall is assumed to be due to release of unlabelled insulin in response to glucose stimulation.

During the second and third phases, the specific activity of insulin released into the medium of high glucose content increases considerably, falling again in the final phase $3 \frac{1}{2}-4 \frac{1}{2} \mathrm{hr}$. from the start of labelling. The specific radioactivity of insulin released into medium of low glucose content remains much the same in all four phases of a single experiment.

Recovery of insulin in immunological purification procedure. Preliminary results with the 'doubleantibody' purification procedure showed that recovery of small quantities of insulin by using this method was satisfactory. Thus in three experiments where $5 \mu \mathrm{g}$. of ox insulin was added to the buffer alone, the mean amount of insulin recoverable after precipitation with antibody and extraction into acidic ethanol was 56.5\% (s.E.M. $\pm 4 \cdot 1 \%$ ). Similar results were obtained from extraction of 131I-labelled insulin in the presence of carrier ox insulin, the radioactivity remaining as a single peak after chromatography of the regenerated insulin on Whatman no. 1 paper in butan-2-ol.

Efficiency of complete extraction procedure. It was decided to determine how much of the insulin present in the medium was recoverable after the extraction and purification technique used. In 14 different media in which rabbit pancreas slices had previously been incubated, the mean recovery of insulin in the final acidic ethanol extract before chromatography and electrophoresis was $19.4 \%$ (s.E.M. $\pm 1.3 \%$ ) of that originally present in the medium.

\section{DISCUSSION}

Extraction procedure. A serious difficulty in studies of insulin biosynthesis in mammalian pancreas has been the isolation of labelled insulin in a state of radiochemical purity (Mallory et al. 1964; Humbel, 1965). The use of immunological techniques, based on the direct precipitation of insulin by antibody, to purify insulin has been described in detail (Taylor et al. 1965). In the present series of experiments, there appeared to be insufficient insulin secreted into the media for the direct precipitation technique to be effective; for this reason it was decided to employ a 'double-antibody' method for purifying insulin, in which insulin bound to antibody is precipitated with an anti$\gamma$-globulin serum. Similar techniques are being widely used in the radioimmunoassay of very small quantities of protein hormones.

From Fig. 1 it is clear that labelled insulin secreted into the medium and isolated by the above procedure has chromatographic and electrophoretic properties very similar to those of unlabelled crystalline ox insulin. In some earlier experiments in which the medium reacted directly with antibody without prior extraction of the insulin, occasional samples gave evidence of inhomogeneity. Subsequently therefore, the medium was extracted with acidified ethanol, and the crude insulin precipitated by ether-ethanol before it reacted with antibody. Although the recovery of insulin was diminished to about $20 \%$ of the total originally present in the medium, the specificity of the method was very greatly increased, and this procedure was adopted in all the experiments reported above.

Labelling of insulin within the pancreas. Insulin was labelled within the $\beta$-cells by incubation of tissue slices in vitro with $\left[{ }^{3} \mathrm{H}\right]$ leucine, in the presence of high concentration of glucose $(250 \mathrm{mg} . / 100 \mathrm{ml}$.). These conditions are known to promote a high rate of incorporation of leucine into insulin (Parry \& Taylor, 1966). It was assumed that the insulin was labelled by biosynthetic mechanisms in this preparation.

In the first series of experiments a labelling period of $1 \mathrm{hr}$. was used, whereas subsequently a period of $20 \mathrm{~min}$. was adopted; this was the shortest time practicable to ensure that insulin of sufficient specific activity was released into the medium for counting after purification.

Release of insulin into medium of low glucose content. It has been known for some time that experiments in which mammalian pancreas slices are incubated in vitro always involve the release of small quantities of insulin into the incubation medium. This takes place in the presence of low concentrations of glucose (Coore \& Randle, 1964; Genuth \& Lebovitz, 1965), or in the complete absence of glucose (Pfeiffer, Telib, Ammon, Melani \& Ditschuneit, 1965). This type of release remains unaltered in the presence of 2,4-dinitrophenol, puromycin or under conditions of anoxia (Coore \& Randle, 1964). Its significance remains doubtful; it may represent a release of insulin as an artifact due to enzymic breakdown of the tissue, or may arise from tissue damage due to handling.

The insulin released into medium of low glucose content possessed a significant amount of label (Tables 2 and 3), although the amount of insulin was small in comparison with that released in the presence of high concentrations of glucose. It was also relatively constant in quantity and in specific radioactivity in each incubation phase of a single experiment. Whether release of insulin at low concentrations of glucose takes place by a similar method in vivo is a matter for conjecture; some insulin has been shown to be released into the pancreatic vein of dogs, even at very low blood 
glucose concentrations after administration of phlorrhizin (Metz, 1960; Seltzer, 1962).

Release of insulin into medium of high glucose content. In earlier experiments in which a $1 \mathrm{hr}$. period of labelling was adopted and in which insulin released into the medium $1 \frac{1}{2}-2 \frac{1}{2} \mathrm{hr}$. after the start of labelling was studied, it appeared that some newly synthesized insulin was being released in response to glucose stimulation (Howell, Parry \& Taylor, 1965). Thus the specific activity of the insulin extracted from the medium of high glucose content was about half of that extracted from media of low glucose content, whereas the amount of insulin released into the former medium increased about fourfold (Table 2).

This was also the case when a much shorter period of labelling (i.e. $20 \mathrm{~min}$.) was used. Under these conditions, in which the insulin released in four successive $1 \mathrm{hr}$. incubation periods was purified, it appeared that newly labelled insulin was being released maximally $2 \frac{1}{2}-3 \frac{1}{2} \mathrm{hr}$. after the start of labelling (Table 3). It should again be emphasized that, although there is some variation between the results of different experiments, the relative results from the different phases of each experiment were in general the same. As has been indicated above, it is difficult to draw firm conclusions about events in phase $A$, and overall conclusions have been made only from the results of phases B, C and D at high glucose concentrations.

During the time taken between synthesis and release it is to be presumed that newly synthesized insulin becomes associated with the $\beta$-granules. This is believed to involve movement of the newly synthesized protein from the rough-surfaced endoplasmic reticulum to the Golgi complex, where granule formation may occur. It has already been suggested on the basis of electron microscopy that the $\beta$-granules are derived from the Golgi complex (Ferreira, 1957; Falkmer \& Olsson, 1962). It is uncertain what further time may be necessary for the $\beta$-granules to move to the periphery of the cells to allow insulin to be released.

These results, demonstrating the release of newly synthesized insulin, show close analogies with those obtained when release of proteins has been studied in other types of secretory cell. Thus in exocrine pancreas radioautography has shown that newly synthesized pancreatic proteins are secreted into the pancreatic ducts by fusion of zymogen granules with the plasma membrane from $2 \mathrm{hr}$. after the rapid injection of $\left[{ }^{3} \mathrm{H}\right]$ leucine (Warshawsky, Leblond \& Droz, 1963; Caro \& Palade, 1964; Van Heyningen, 1964). In thyroid tissue, newly synthesized thyroid hormone also begins to appear in the colloid of the gland $3 \frac{1}{2} \mathrm{hr}$. after the injection of radioactive leucine (Nadler, Young, Leblond \& Mitmaker, 1964). A similar sequence of events is also seen during the formation of granules in the adenohypophysis (Racadot, Olivier, Porcile \& Droz, 1965).

There therefore seems to be some uniformity in the time taken for secretory cells to synthesize and transfer their exportable proteins to the outside of the cell through the movement of granules. No supporting evidence has been obtained in these experiments for the rapid release of insulin by types of intracellular pathway that do not involve the $\beta$-granules.

We thank Professor J. Anderson for much advice and encouragement, and Miss M. Sandiford and Mr D. G. Parry for valuable help. Financial assistance towards the cost of this work from the Medical Research Council, the British Diabetic Association and British Insulin Manufacturers is gratefully acknowledged.

\section{REFERENCES}

Caro, L. G. \& Palade, G. E. (1964). J. Cell Biol. 20, 473.

Coore, H. G. \& Randle, P. J. (1964). Biochem. J. 93, 66. Falkmer, S. \& Olsson, R. (1962). Acta endocr., Copenhagen, $39,32$.

Ferreira, D. (1957). J. Ultrastruct. Res. 1, 14.

Genuth, S. \& Lebbvitz, H. E. (1965). Endocrinology, 76, 1093.

Gey, G. O. \& Gey, M. K. (1936). Amer. J. Cancer, 27, 45.

Grodsky, G. \& Tarver, H. (1956). Nature, Lond., 177, 223.

Hales, C. N. \& Randle, P. J. (1963). Biochem. J. 88, 137.

Howell, S. L., Parry, D. G. \& Taylor, K. W. (1965). Nature, Lond., 208, 487.

Humbel, R. E. (1965). Proc. nat. Acad. Sci., Wash., 58, 853.

Jones, V. E. \& Cunliffe, A. C. (1961). Nature, Lond., 192 , 136.

Mallory, A., Smith, G. H. \& Taylor, K. W. (1964). Biochem. J. 91, 484.

Metz, R. (1960). Diabetes, 9, 89.

Nadler, N. J., Young, B. A., Leblond, C. P. \& Mitmaker, B. (1964). Endocrinology, 74, 333.

Parry, D. G. \& Taylor, K. W. (1966). Biochem. J. 100, 2 c.

Peters, T., jun. (1962). J. biol. Chem. 237, 1186.

Pfeiffer, E. F., Telib, M., Ammon, J., Melani, F. \& Ditschuneit, H. (1965). Diabetologia, 1, 131.

Racadot, J., Olivier, L., Porcile, E. \& Droz, B. (1965). C.R. Acad. Sci., Paris, 261, 2972.

Seltzer, H. S. (1962). J. clin. Invest. 41, 289.

Taylor, K. W., Gardner, G., Parry, D. G. \& Jones, V. E. (1965). Biochim. biophys. Acta, 100, 521.

Taylor, K. W. \& Smith, G. H. (1964). Biochem. J. 91, 491.

Van Heyningen, H. E. (1964). Anat. Rec. 148, 485.

Warshawsky, H., Leblond, C. P. \& Droz, B. (1963). J. Cell Biol. 16, 1.

Williamson, J. R., Lacy, P. E. \& Taylor, K. W. (1967). Biochem. J. 102, 928. 